\title{
Proteomic analysis of soybean leaves in a compatible and an incompatible interaction with Phakopsora pachyrhizi
}

\begin{abstract}
Asian soybean rust (ASR), which is incited by the fungus Phakopsora pachyrhizi, is considered one of the most aggressive diseases to the soybean culture. There are no commercial cultivars immune to the pathogen and the control measure currently used is the application of fungicides that harms the environment and increases production costs. For a better understanding of the host's response to the pathogen at the molecular level, two soybean genotypes were analyzed (PI561356, resistant to ASR and Embrapa 48, susceptible) at 72 hours and 192 hours after inoculation with spores of $P$. pachyrhizi. Leaf protein profiles of the plants were compared by two-dimensional electrophoresis associated with mass spectrometry (MS). Twenty-two protein spots presented different levels when the two treatments were compared (inoculated vs. non-inoculated). From those, twelve proteins were identified by MS analysis. Some of them are involved in metabolic pathways related to plant defense against pathogens, as in the case of carbonic anhydrase, 1-deoxy-D-xylulose5 -phosphate reductoisomerase, fructose-bisphosphate aldolase and glutamine synthetase. The possible biochemical-physiological meanings of our findings are discussed.
\end{abstract}

Keywords

Glycine max $\bullet$ Phakopsora pachyrhizi $\bullet$ 2-D electrophoresis $\bullet$ MALDI $\bullet$ mass spectrometry

C 2013 Mateus Rodrigues Pereira et al., licensee Versita Sp. z o. o.

This work is licensed under the Creative Commons Attribution-NonCommercial-NoDerivs license, which means that the text may be used for non-commercial purposes, provided credit is given to the author
Mateus Rodrigues Pereira' Bianca Castro Gouvêa', Francismar Corrêa Marcelino-Guimarães ${ }^{2}$,

Humberto Josué de Oliveira Ramos ${ }^{3,4}$ Maurilio Alves Moreira ${ }^{3,4}$ Everaldo Gonçalves de Barros ${ }^{1,3,5 *}$

\begin{tabular}{|c|c|}
\hline $\begin{array}{l}\text { 'Departamento de Biologia Geral, } \\
\text { Universidade Federal de Viçosa, Viçosa, } \\
\text { Minas Gerais, Brazil }\end{array}$ & $\begin{array}{l}{ }^{4} \text { Departamento de Bioquímica e Biologia } \\
\text { Molecular, Universidade Federal de } \\
\text { Viçosa, Viçosa, Minas Gerais, Brazil }\end{array}$ \\
\hline $\begin{array}{l}\text { Embrapa Soja, Londrina, Paraná, Brazil } \\
\text { 3Instituto de Biotecnologia Aplicada à } \\
\text { Agropecuária (BIOAGRO), Universidade } \\
\text { Federal de Viçosa, Viçosa, Minas } \\
\text { Gerais, Brazil }\end{array}$ & $\begin{array}{l}\text { 5Programa de Pós-Graduação em } \\
\text { Ciências Genômicas e Biotecnologia, } \\
\text { Universidade Católica de Brasília, } \\
\text { Brasília, DF, Brazil }\end{array}$ \\
\hline
\end{tabular}

Received 12 September 2013 Accepted 10 October 2013

\section{Introduction}

Among the main factors limiting soybean (Glycine max (L.) Merrill) crop are the diseases [1]. More than 100 diseases can affect this culture [2], of those at least 50 have already been identified in Brazil [3].

Asian soybean rust (ASR), incited by the fungus Phakopsora pachyrhizi Sydow, is a major disease limiting soybean production in tropical and subtropical areas worldwide causing yield losses from 10 to $80 \%$ [4]. In 2001, ASR became one of the most relevant problems in Brazilian agriculture [5].

P. pachyrhizi infects more than 150 species of plants from more than 53 genera including soybean, related Glycine species, and other hosts in the Fabaceae [6]. It is an obligate biotrophic plant-pathogenic fungus that colonizes leaf tissue [7], causing rapid yellowing and premature leaf fall, hampering full grain formation $[8,9]$. The life cycle begins with uredospores coming uredinias produced into infected plants in other soybean fields. Under favorable conditions, after reaching the leaves, the spores germinate with a minimum of six hours, and the symptoms may appear within five to seven days. The urediniosporal lesions begin to be produced from nine to twelve days after germination and penetration [10]. Symptoms begin in the lower leaves of the plant and are characterized by tiny dots of darker color compared to healthy tissue [9]. In these dark spots, lower protuberances are observed characterizing the beginning of the formation of fruiting structures of the fungus. Progressively, the bulge acquires color light brown to brown-black, which opens up pores that expel uredospores [11].

At least six ASR resistance genes have been described so far: Rpp1 [12], Rpp2 [13], Rpp3 [14], Rpp4 [15], Rpp5 [16] and Rpp6 [17]. The immune reaction, where no visible symptoms are observed, has only been reported with Rpp1 when inoculated with certain isolates [4,7]. Resistance responses mediated by the Rpp2 to Rpp6 loci limit fungal growth and sporulation through the formation of visible reddish-brown lesions suggestive of a hypersensitive-like response (HR) $[16,18]$. Tan-colored lesions and fully sporulating uredenia generally indicate a susceptible interaction to ASR [7]. The resistance sources identified are all specific to certain strains of $P$. pachyrhizi [18]. Therefore, the effectiveness of these genes $R$ is limited (partial) due to the high virulence and variability of the pathogen [19]. There are no immune commercial cultivars available and the current control measures include the heavy 
use of fungicides which increases production costs and harm the environment $[7,20]$.

However, genetic resistance is the most effective and inexpensive measure for disease control [7]. Understanding the molecular, physiological and cellular mechanisms involved in the soybean response to this pathogen is an excellent strategy to screen genes involved in the activation of metabolic pathways related to the defense of the host to the pathogen. Understanding the host responses at the molecular level is certainly essential for effective control of the disease, and the molecular basis for rust resistance remained largely unknown in soybean [21]. The study of soybean genes that are differently expressed as a response to $P$. pachyrhizi can aid the identification of important genes involved in the resistance response and provide tools for genetic breeding programs for creation of soybean cultivars resistant to ASR [22,23]. Although molecular studies are being conducted on this pathosystem, there is still little information on the molecular basis of this interaction [21,24-26]. To develop rust-resistant soybean cultivars, a better understanding of the molecular basis and essential genes involved in defense responses is a key to control this disastrous disease [21].

The proteome can be defined as the set of proteins present in a tissue, cell or biological system in a given moment of cell life, or as the profile of cell proteins expressed by the genome of an organism under a determined physiological situation. The proteomic analysis refers to the systematic assessment of the proteome, in order to compare the gene expression of cells, tissues or organisms in distinct physiological moments, for example, in sick and healthy tissues, treated and nontreated, resistant and susceptible [27]. Recently, Wang et al. (2012) [21] identified proteins with altered levels in a resistant soybean cultivar (SX6907) at two different time points (12 and 24 hours) upon inoculation with $P$. pachyrhizi. Using the same methodologies like two-dimensional electrophoresis (2$\mathrm{DE}$ ) and mass spectrometry (MS), the present study aimed at identifying proteins that accumulate differentially in response to $P$. pachyrhizi in two soybean genotypes, PI561356, carrying the Rpp1 gene [19] (resistant) and Embrapa 48 (susceptible) at two different time points (72 and 192 hours) after inoculation. As a result of this interaction, twelve differentially accumulated proteins were detected and identified in this study. These proteins participate in metabolic pathways related to plant defense to pathogens.

\section{Methods}

\subsection{Plant material and inoculation}

Seeds of the genotypes used in this experiment were provided by the Soybean Active Germplasm Bank of Embrapa Soja, Londrina - PR, Brazil. The plants were sprayed at developmental stage V2 with a suspension of a population of $P$. pachyrhizi collected in the Embrapa Soja fields, located in Londrina, Paraná state, and maintained on cultivar BRSMSBacuri in a greenhouse. Uredioniospores were collected by tapping infected leaves over a plastic tray. The spores were then resuspended in distilled water containing $0.05 \%(\mathrm{v} / \mathrm{v})$ polyoxyethylenesorbitan monolaurate (Tween 20) to a final concentration of approximately 70,250 spores $/ \mathrm{mL}$. This concentration was defined by preliminary infection experiments performed by our breeding group. The leaves from two distinct genotypes (PI561356, resistant to ASR and Embrapa 48, susceptible) were collected 72 and 192 h.a.i. (hours after inoculation). At 72 h.a.i. soybean response to the pathogen is intense [22-24] and also close to 192 h.a.i. when the fungus reaches the uredinia (urediniospores) production stage [26]. For each genotype and each time point, leaves of control plants (mock: non-inoculated) were also collected. Eight treatments were analyzed, with three biological replications for each treatment.

\subsection{Protein extraction}

Leaf protein extraction was based on the SDS/phenol method [28] with some modifications. The leaves (2-3 g) were powdered in the presence of liquid $\mathrm{N}_{2}$ in a mortar and pestle. The powder was transferred to a $50 \mathrm{~mL}$ Falcon tube. After $\mathrm{N}_{2}$ evaporation, $20 \mathrm{~mL}$ extraction buffer (1\% polyvinylpolypyrrolidone, 2\% $\beta$-mercaptoethanol, $1 \mathrm{mM}$ phenylmethylsulfonyl fluoride (PMSF) in cold acetone) were added to the tube. After brief vortexing, the mixture was sonicated at $30 \%$ of the maximum power of the UltraSonic Processor Model GE-50 (Thomas Scientific, Swedesboro, New Jersey, USA) (amplitude of $70 \mathrm{~dB}$ ) and centrifuged at $6,000 \mathrm{~g}$, at $4{ }^{\circ} \mathrm{C}$, for $15 \mathrm{~min}$. The pellet was washed successively in acetone (twice), 10\% trichloroacetic acid (TCA) in acetone (four times), 10\% TCA in water (twice), $80 \%$ acetone (twice) and $80 \%$ ethanol (once), and dried overnight at room temperature. For the washes the pellet was resuspended by vortexing and centrifuged at $6,000 \mathrm{~g}$, for 10 $\min$, at $4^{\circ} \mathrm{C}$.

The final pellet obtained was resuspended in $10 \mathrm{~mL}$ dense SDS buffer ( $0.75 \mathrm{M}$ sucrose; $2 \%$ sodium lauryl sulfate (SDS); $0.1 \mathrm{M}$ Tris-HCl, pH 8.0; $2 \% \beta$-mercaptoethanol; $1 \mathrm{mM}$ PMSF) and kept at room temperature for $10 \mathrm{~min}$. The mixture was transferred to a $15 \mathrm{~mL}$ Falcon tube to which $5 \mathrm{~mL}$ buffered phenol $(\mathrm{pH} 8.0)$ were added. The mixture was kept on ice for $10 \mathrm{~min}$. During this period the mixture was vortexed three times for 30 s each time and then centrifuged at $6,000 \mathrm{~g}$ for $10 \mathrm{~min}$, at $4{ }^{\circ} \mathrm{C}$. The phenolic phase was transferred to a fresh $50 \mathrm{~mL}$ Falcon tube to which $20 \mathrm{~mL} 0.1 \mathrm{M}$ ammonium acetate in methanol were added. After $30 \mathrm{~min}$ at $-20^{\circ} \mathrm{C}$, the tube was centrifuged at $6,000 \mathrm{~g}$ for $15 \mathrm{~min}$, at $4^{\circ} \mathrm{C}$. The pellet obtained was washed as previously described in $0.1 \mathrm{M}$ ammonium acetate in methanol (twice), $80 \%$ acetone (twice) and $70 \%$ ethanol (once). The final pellet was dried at room temperature overnight, resuspended in sample buffer (7M urea, $2 \mathrm{M}$ thiourea and 4\% (3-[(3-cholamidopropyl)dimethylammonio]-1-propane sulfonate (CHAPS)) and sonicated at $10 \%$ of the maximum power of the UltraSonic Processor Model GE-50 (Thomas Scientific, Swedesboro, New Jersey, USA). The Bradford Method [29] was used for protein quantification and the protein extract was stored at $-80^{\circ} \mathrm{C}$. 
2.3 Separation of total proteins by two-dimensional gel electrophoresis (2-DE)

\subsubsection{Rehydration and sample loading}

The samples $(1,000 \mu \mathrm{g}$ of proteins) were loaded during the reswelling process in a rehydration apparatus IPG BOX (GE Healthcare, Piscataway, NJ, USA) at $20^{\circ} \mathrm{C}$ for $12 \mathrm{~h}$. For the first dimension, $24 \mathrm{~cm}$ gel strips were used (with a linear $\mathrm{pH}$ gradient ranging from 3.0 to 10.0). To rehydrate each strip, $450 \mu \mathrm{L}$ of a mixture containing the solubilized proteins in $7 \mathrm{M}$ urea, $2 \mathrm{M}$ thiourea, 4\% CHAPS and 2.5\% IPG buffer plus DeStreak solution (GE Healthcare, Piscataway, NJ, USA) [30] were used.

\subsubsection{Isoelectric focusing (IEF)}

IEF was conducted in the equipment IPGphor III (GE Healthcare, Piscataway, NJ, USA). Electrophoresis conditions were according to the GE Healthcare Handbooks [30], with some modifications: 1) $200 \mathrm{~V}$ for $18 \mathrm{~h}$; 2) $500 \mathrm{~V}$ for $1 \mathrm{~h}$; 3) $800 \mathrm{Vh}$ in gradient until $1,000 \mathrm{~V}$; 4) $16,500 \mathrm{Vh}$ in gradient until $10,000 \mathrm{~V}$; 5) $27,000 \mathrm{Vh}$ in one step of $10,000 \mathrm{~V}$. After the IEF, the strips were stored at -80 ${ }^{\circ} \mathrm{C}$ until the second dimensional electrophoresis.

\subsubsection{Equilibration of the gel strips}

After the IEF, the strips were equilibrated in $10 \mathrm{~mL}$ equilibrating buffer $(75 \mathrm{mM}$ Tris- $\mathrm{HCl}, \mathrm{pH}$ 8.8, 6M urea, 29.3\% glycerol, $2 \%$ SDS and $0.002 \%$ bromophenol blue) in two 30 -min stages in order to reduce and alkylate the proteins. In the first stage, 180 $\mathrm{mg}$ dithithreitol (DTT) were added to the equilibrating buffer. In the second stage, $430 \mathrm{mg}$ iodoacetamide were added to 10 $\mathrm{mL}$ fresh equilibrating buffer [30]. The strips were then briefly incubated in $1 \mathrm{X}$ running buffer [31] and submitted to the second electrophoresis dimension (SDS-PAGE).

\subsubsection{Electrophoresis in polyacrylamide gel (SDS- PAGE)}

The second dimension electrophoresis was based on Laemmli (1970) [31] in a $12.5 \%$ polyacrylamide gel (30\% acrylamide, $2.6 \%$ $\mathrm{N}, \mathrm{N}$ '-methylenebisacrylamide), in a DaltSix unit (GE Healthcare, Piscataway, NJ, USA). Separation was performed at $10 \mathrm{~mA} / \mathrm{gel}$ for $45 \mathrm{~min}$ and then at $40 \mathrm{~mA} / \mathrm{gel}$ until the bromophenol blue reached the gel lower limit. The temperature was kept at $8^{\circ} \mathrm{C}$ using a thermostatic circulator.

\subsubsection{Analysis of the spots}

The 2D gels were stained with coomassie blue G-250 [30]. They were then photo digitalized in an Image Scanner III (GE Healthcare, Piscataway, NJ, USA) and the images were calibrated with the aid of the software Labscan (GE Healthcare, Piscataway, NJ, USA). For the comparative analysis of the images, the software ImageMaster 2D Platinum 7.5 (GE Healthcare, Piscataway, NJ, USA) was used. Image analysis included spot detection, spot measurement, background subtraction and spot matching of three biological replicates gel. Prior to performing spot matching between gel images, one gel image was selected as reference. The amount of protein of each spot was expressed as the volume of that spot which was defined as sum of the intensities of all the pixels that make up that spot. To correct the variability and to reflect the quantitative variations of protein spots, the spot volumes were normalized as a percentage (\%Vol) of the total volume in all the spots in the gel. The ratio method was used for the overlapping analysis between the mock control and the inoculated treatment for each genotype and each inoculation time, and to evaluate gene expression changes. Matched spots showing a ratio overlap values over 1.5 and significant oneway ANOVA $(p<0.05)$ analysis were considered over or under accumulated.

\subsection{In-gel protein digestion}

The regions containing the gel spots corresponding to the differentially accumulated proteins were removed from the gel and the proteins were submitted to trypsinolysis [32]. The gel pieces were transferred to siliconized PCR tubes $(200 \mu \mathrm{L})$ previously washed with methanol. Destaining was performed in four washes, two of $1 \mathrm{~h}$ each, one overnight, and one of $1 \mathrm{~h}$ the next day. All the washes were done at room temperature, with agitation $(750 \mathrm{rpm})$ in a thermomixer (Eppendorf, Hamburg, Germany) with a $50 \%$ acetonitrile solution containing $25 \mathrm{mM}$ ammonium bicarbonate, $\mathrm{pH}$ 8.0. The destaining solution was discarded and the gel pieces were dehydrated in pure acetonitrile for two 5-min periods and dried in a Speed Vac Concentrator Plus (Eppendorf, Hamburg, Germany) for $15 \mathrm{~min}$. The proteins were then reduced with $65 \mathrm{mM}$ DTT in $100 \mathrm{mM}$ ammonium bicarbonate, $\mathrm{pH}$ 8.0, for $30 \mathrm{~min}$, at $56{ }^{\circ} \mathrm{C}$, in a thermomixer, at $500 \mathrm{rpm}$. After this step, the proteins were alkylated with $200 \mathrm{mM}$ iodoacetamide in $100 \mathrm{mM}$ ammonium bicarbonate, $\mathrm{pH} 8.0$, for $30 \mathrm{~min}$, at room temperature, in the absence of light, in a thermomixer, at $500 \mathrm{rpm}$. Sequentially, the gel pieces were twice washed in $100 \mathrm{mM}$ ammonium bicarbonate, $\mathrm{pH}$ 8.0, for $10 \mathrm{~min}$, dehydrated in pure acetonitrile for $5 \mathrm{~min}$ and after an additional dehydration step they were dried in a Speed Vac for $15 \mathrm{~min}$. For the tryptic digestion Trypsin Gold V5280, mass spectrometry grade (Promega, Madison, Wisconsin, USA) was used. A stock was prepared out of $100 \mu \mathrm{g}$ enzyme in $100 \mu \mathrm{L} 50 \mathrm{mM}$ acetic acid $(1,000 \mathrm{ng} / \mathrm{\mu L})$. For the cleavage solution the stock enzyme solution was diluted in $40 \mathrm{mM}$ ammonium bicarbonate, $\mathrm{pH} 8.0$, in $10 \%$ acetonitrile to a final concentration of $25 \mathrm{ng} / \mu \mathrm{L}$. To each tube $20 \mu \mathrm{L}$ cleavage solution was added, enough to cover the gel pieces. The tubes were kept on ice for $45 \mathrm{~min}$ to keep the enzyme inactive and prevent premature trypsinolysis. After this period, $50 \mu \mathrm{L} 40 \mathrm{mM}$ ammonium bicarbonate, $\mathrm{pH} 8.0$, in $10 \%$ acetonitrile were added to each tube. The samples were then incubated at $37^{\circ} \mathrm{C}$ for $16 \mathrm{~h}$ in a thermomixer at $500 \mathrm{rpm}$. After digestion, the gel pieces were incubated in an ultrasonic bath Model USC 1880 (Thornton-Unique, Indaiatuba, SP, Brazil) for $10 \mathrm{~min}$, vortexed for $20 \mathrm{~s}$ and the solution containing the tryptic peptides was transferred to a fresh tube. The remaining peptides in the gel pieces were removed in two sequential stages by adding to each tube $30 \mu \mathrm{L} 5 \%$ formic acid in $50 \%$ acetonitrile, vortexing for $20 \mathrm{~s}$ and incubating $15 \mathrm{~min}$ at room temperature, 2 $\mathrm{min}$ in the ultrasound bath and additional vortexing for $20 \mathrm{~s}$. The 
solution was removed and added to the tube containing the first round extract. The samples, containing tryptic peptides, were concentrated until about $10 \mu \mathrm{L}$ in a SpeedVac and later desalted in a Zip Tip C18 column (Millipore, Billerica, MA, USA).

\subsection{Mass spectrometry and protein identification}

Mass spectra of the tryptic peptides were obtained in a MALDI-TOF/TOF mass spectrometer model Ultraflex III (Bruker Daltonics, Bremen, Germany). The samples of tryptic peptides were mixed with $\alpha$-cyano-4-hydroxyl cinnamic acid (Bruker Daltonics, Bremen, Germany) in a proportion of 1:1. The mass spectra obtained were processed using Flex analysis software (Bruker Daltonics, Bremen, Germany) and a peak list (xml and mgf format) was used for identification of the proteins by the peptide mass fingerprinting (PMF) method and by peptide fragment fingerprinting (PFF), respectively using the Mascot software against the $\mathrm{NCBI}$ (http://www.ncbi.nlm.nih.gov/), Swissprot (http://web.expasy.org/docs/swiss-prot_guideline. html) and Glycine max (Phytozome) (http://www.phytozome. net/search.php) protein databases. For the search the following parameters were considered: a mass tolerance of $50 \mathrm{ppm}$ for the parental ion, fixed modification for carbamidomethylation of cysteine residues and variable modification for oxidation of methionine residues. For positive identification, the following criteria were used: significant Mascot score $(p$-value $<0.05)$ for at least six peptides showing matches (PMF). Additionally, positive protein assignments required greater than $20 \%$ sequence coverage and less than $25 \%$ deviation between theoretical and experimental MW values obtained from calibrated 2D gels. Positive identifications by PFF were considered valid for at least three peptides with significant Scaffold score ( $p>95 \%)$ for peptides and proteins, after visual inspection of matches. All identifications were verified manually.

\section{Results}

At the time point of 72 h.a.i., 716 well resolved spots on average were detected in the six gels loaded with total proteins from the susceptible soybean genotype Embrapa 48 (inoculated and mock plants). The number of matches was 580 , but no spot with significant variation in $\%$ Vol were detected. In the case of resistant genotype PI561356, 711 well resolved spots were detected, with 552 matches, of which 13 showed significant variation in \% Vol and nine were identified using high quality MS spectra (Table 1 and Figure $1 \mathrm{~A}$ ): translationally controlled tumor protein (TCTP), gamma-glutamyl hydrolase, small subunit ribosomal protein $\mathrm{S} 1$, elongation factor 1 -alpha, three binding proteins to Rubisco subunit beta, glutamine synthetase and fructose-bisphosphate aldolase.

At the time point of 192 h.a.i., 1,449 well resolved spots were detected in the gels corresponding to genotype PI561356 (inoculated and mock control plants), with 790 matches. Four spots with significant variation in \%Vol were detected but the quality of the mass spectra of the corresponding proteins did not allow their proper identification. For genotype Embrapa 48, 1,367 well resolved spots were detected, with 779 matches, and five spots showed significant variation in \%Vol, three of which were identified (Table 1 and Figure 1B): chloroplast glyceraldehyde3-phosphate dehydrogenase subunit A (GAPDHa), 1-deoxy-Dxylulose-5-phosphate reductoisomerase (DXR) and carbonic anhydraseThe protein accumulation level differences between inoculated and mock plants based on spot \%Vol at 72 and 192 h.a.i. are depicted in Table 2.

\section{Discussion}

Identification of differentially accumulated proteins in both time points analyzed enabled some inferences on their possible roles during host-pathogen interaction. In our analysis, we found a reduced synthesis of TCTP in genotype PI561356 72 h.a.i.. Comparatively, Hill et al. (1999) [33] analyzed genes of Gossypium hirsutum expressed in response to infection with Verticillium dahliae. In this interaction, the mRNA levels for the TCTP were lower in inoculated plants (96 h.a.i.) in relation to mock control plants. In rice, Zhao et al. (2008) [34] detected increased levels of mRNA for this same protein 12 h.a.i. with Rhizoctonia solani. By a proteomic approach, Liao et al. (2009) [35] detected increased levels of TCTP in leaves of two isogenic lines of rice (C101A51 and CO39, incompatible and compatible types, respectively) twelve hours after the application of the elicitor CS B I, purified from $\mathrm{ZC13}$, a race of the rice blast fungus Magnaporthe grisea. The levels of this protein are highly regulated in response to a wide variety of extra-cellular signals and cellular conditions [36]. Several studies found changes in TCTP transcript or protein levels under diverse physiological conditions, such as light, aluminum stress, cold stress, Agrobacterium tumefaciens-mediated transformation, egg cell fertilization, or water deficit [37-42]. TCTP operates in various cellular processes like microtubule organization and ion homeostasis [36]. Studies have mentioned that it is capable of binding with tubulin as well as with calcium [43-45]. It is synthesized in mitotically active tissues, showing reduced accumulation in cells that are not actively dividing [46]. According to Li et al. (2001) [47], this protein has also antiapoptotic functions. Programmed cell death (PCD) is an orderly process of cellular suicide that requires active gene expression [48]. In plants, it has been suggested that PCD is part of the plant response to pathogen invasion, causing the formation of a localized lesion of dead cells that limits cell-to-cell transfer of the pathogen in a process known as the HR (hypersensitive reaction) $[49,50]$. The reduced level of TCTP found in leaf cells of the genotype PI561356 72 h.a.i. with $P$. pachyrhizi found in this study, evidences the occurrence of HR by the PCD bearing in mind the functions proliferative and anti-apoptotic of the TCTP. We could speculate that a lower level of TCTP as a response to inoculation could be a physiological and cellular response to induce apoptosis in sites near injuries caused by the pathogen.

In the present study, the enzyme fructose-bisphosphate aldolase, which is part of the pentose phosphate pathway, showed increased levels in plants of genotype PI561356 72 h.a.i.. In fact, the spot corresponding to this enzyme was not detected 


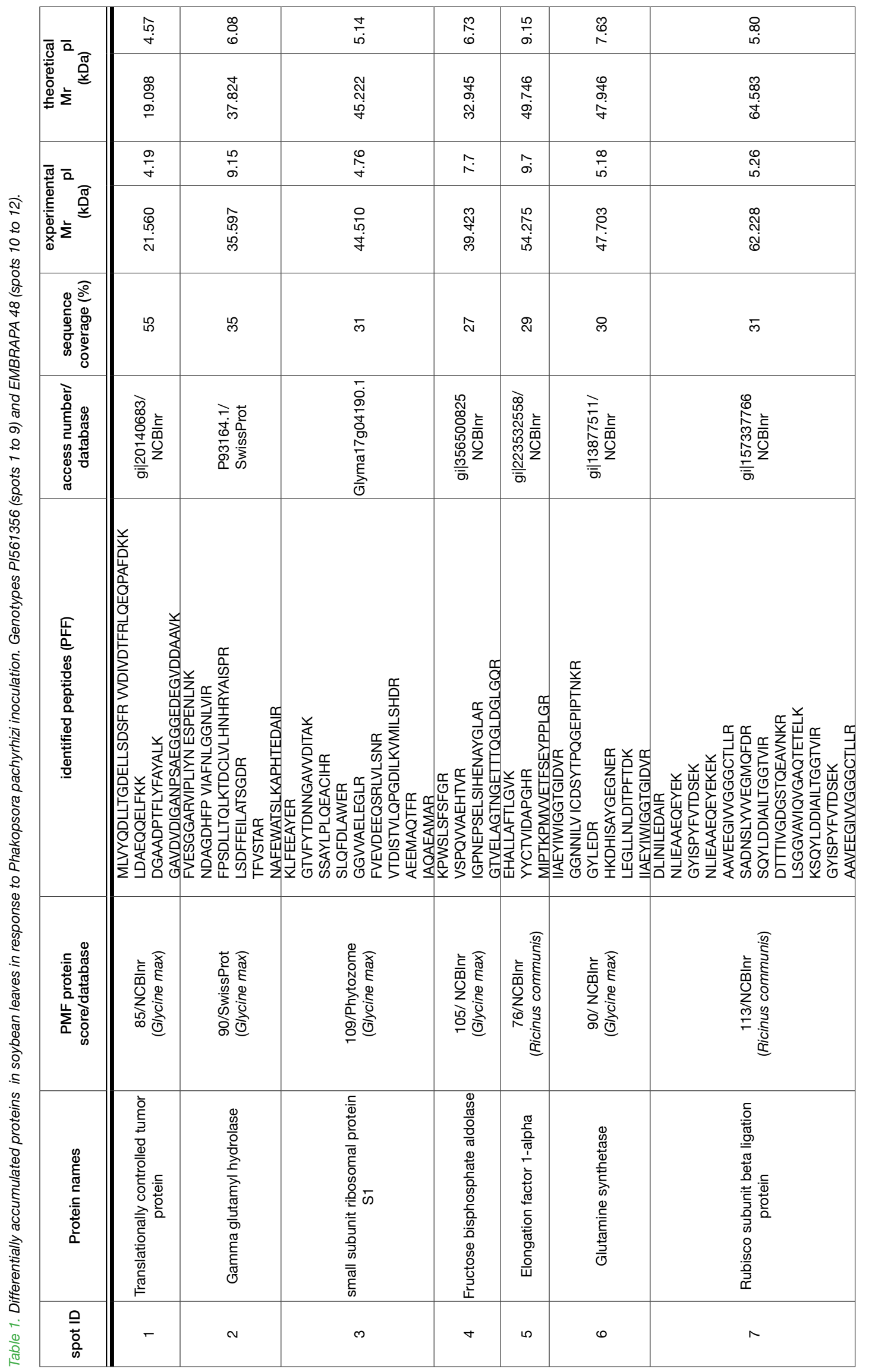




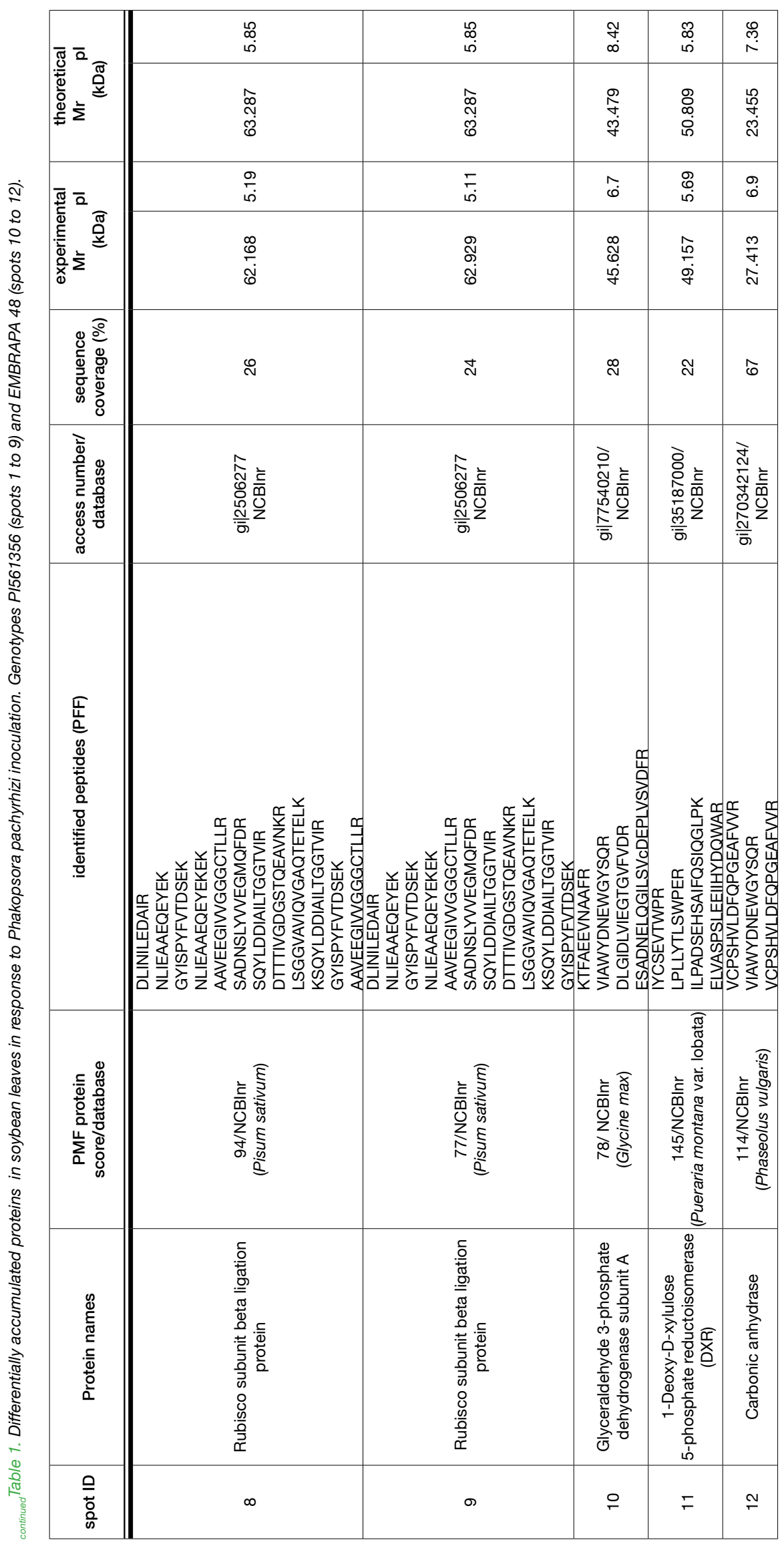


A

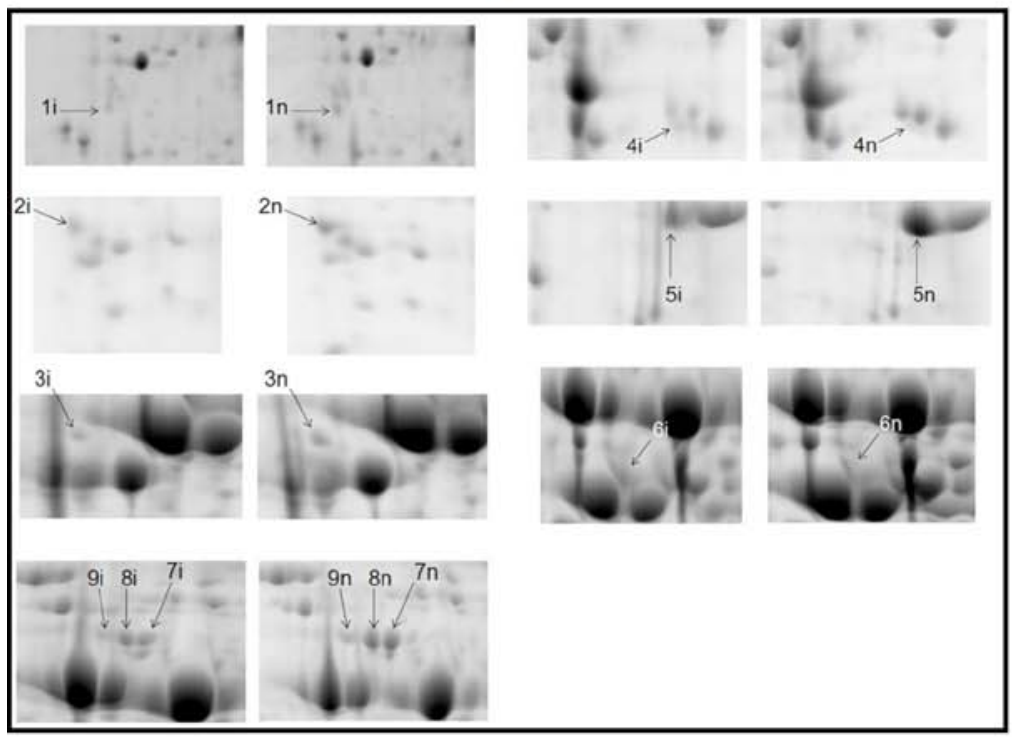

B

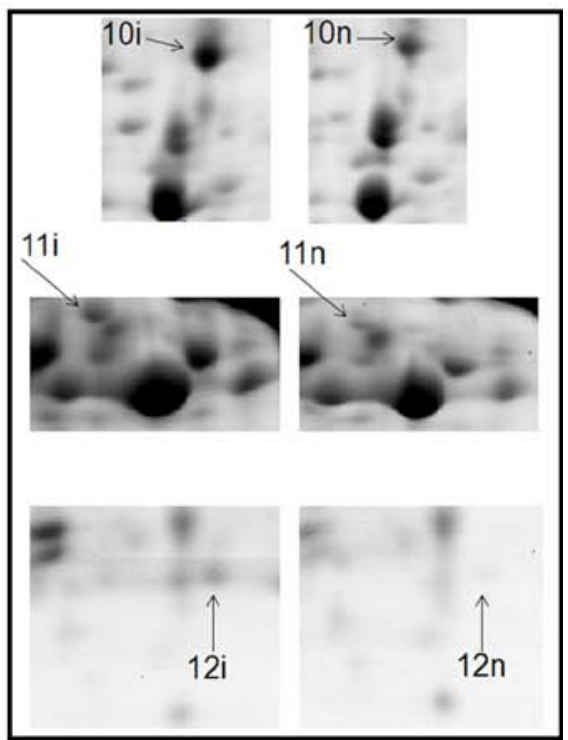

Figure 1. A: Spots corresponding to proteins differentially accumulated in partially resistant genotype PI561356 72 h.a.i. The symbols are as follows: $1 \mathrm{i}$ and $1 \mathrm{n}$ : tumoral protein translationally controlled; $2 \mathrm{i}$ and $2 \mathrm{n}$ : gamma glutamyl hydrolase; $3 i$ and $3 n$ : small subunit ribosomal protein S1; $4 i$ and 4n: fructose bisphosphate aldolase; $5 i$ and 5n: elongation factor 1-alpha; 6i and 6n: glutamine synthetase; 7i, 7n, 8i, 8n, 9i and 9n: Rubisco beta subunit binding protein. The indexes " $i$ " and " $n$ " indicate that the plants have been inoculated (i) or non-inoculated ( $n$ : mock) with P. pachyrhizi.

B: Spots corresponding to proteins differentially accumulated in susceptible genotype Embrapa 48192 h.a.i. The symbols are as follows: 10 i and 10n: glyceraldehyde-3-phosphate dehydrogenase subunit $A ; 11 i$ and 11n: 1-deoxy-D-xylulose-5-phosphate-reductoisomerase (DXR); $12 i$ and 12n: carbonic anhydrase. The indexes " $i$ " and " $n$ " indicate that the plants have been inoculated (i) or non-inoculated ( $n$ : mock) with P. pachyrhizi.

Table 2. Relative protein levels based on the spots mean \%Volumes of inoculated (I) and non-inoculated plants (Mock) ( $N$ ).

\begin{tabular}{|c|c|c|c|c|}
\hline \multicolumn{5}{|c|}{ PI561356 (72 h.a.i.) } \\
\hline spot & \multirow{2}{*}{ Protein putative identification } & \multicolumn{2}{|c|}{ mean $\%$ volume $\pm S D$} & \multirow{2}{*}{$\begin{array}{l}\text { accumulation level } \\
\text { difference }\end{array}$} \\
\hline & & 1 & $\mathbf{N}$ & \\
\hline 1 & Translationally controlled tumor protein & $0.016 \pm 0.003$ & $0.024 \pm 0.007$ & $(-) 1.50 x$ \\
\hline 2 & Gamma glutamyl hydrolase & $0.038 \pm 0.011$ & $0.094 \pm 0.025$ & (-) $2.47 x$ \\
\hline 3 & small subunit ribosomal protein S1 & $0.030 \pm 0.006$ & $0.064 \pm 0.017$ & $(-) 2.13 x$ \\
\hline 4 & Fructose bisphosphate aldolase & $0.019 \pm 0.009$ & ND & NA \\
\hline 5 & Elongation factor 1-alpha & $0.347 \pm 0.061$ & $0.684 \pm 0.329$ & $(-) 1.97 x$ \\
\hline 6 & Glutamine synthetase & $0.226 \pm 0.097$ & $0.160 \pm 0.049$ & (+) $1.41 \mathrm{x}$ \\
\hline 7 & Rubisco beta subunit binding protein & $0.066 \pm 0.015$ & $0.235 \pm 0.062$ & $(-) 3.56 x$ \\
\hline 8 & Rubisco beta subunit binding protein & $0.082 \pm 0.023$ & $0.236 \pm 0.067$ & $(-) 2.88 x$ \\
\hline 9 & Rubisco beta subunit binding protein & $0.041 \pm 0.015$ & $0.093 \pm 0.015$ & $(-) 2.27 x$ \\
\hline \multicolumn{5}{|c|}{ Embrapa 48 (192 h.a.i.) } \\
\hline 10 & Glyceraldehyde-3-phosphate dehydrogenase subunit A & $0.332 \pm 0.035$ & $0.155 \pm 0.071$ & $(+) 2.14 x$ \\
\hline 11 & 1-deoxy-D-xylulose-5-phosphate-reductoisomerase (DXR) & $0.061 \pm 0.012$ & $0.024 \pm 0.014$ & $(+) 2.54 \mathrm{x}$ \\
\hline 12 & Carbonic anhydrase & $0.060 \pm 0.002$ & ND & NA \\
\hline
\end{tabular}

The signals (+) and (-) indicate increase and decrease on protein synthesis as response to $P$. pachyrhizi inoculation, respectively. ND =not detected. NA = does not apply.

in mock plants. This might have been due to limitations of the $2 \mathrm{D}$ electrophoresis technique that tends not to allow detection of low abundance proteins [30]. It is also conceivable that the concentration of this enzyme in mock plants was below the limits established for image analysis using the software ImageMaster. The pentose phosphate pathway is one of the main routes for the production of phenolic compounds [26], which are responsible for activation of defense mechanisms. Tremblay et al. (2010) [26] 
showed that the levels of transcripts corresponding to proteins of this pathway were lower in soybean plants inoculated with $P$. pachyrhizi compared to mock plants. Fructose-bisphosphate aldolase was among these proteins. According to these authors their findings are in agreement with the fact that the susceptible cultivar they used (cv. Williams 82) could not build an efficient defense mechanism. Liao et al. 2009 [35] also found changes in the levels of fructose bisphosphate aldolase that showed down-regulated at 12 hours after the application of the elicitor CS B I (of the race ZC13 of the fungus Magnaporthe grisea) in leaves of both isogenic lines of rice C101A51 and CO39. Wang et al. (2012) [21] also detected increased levels of fructosebisphosphate aldolase in a soybean resistant cultivar (SX6907) inoculated with $P$. pachyrhizi spores at 12 and 24 h.a.i..

Our data also showed decreased levels of a chloroplast ribosomal protein that is part of the 305 subunit (small subunit ribosomal protein S1) and of elongation factor 1-alpha in genotype PI561356 72 h.a.i.. Several studies on the biotrophic interactions between fungus and host plant show that the translational activity and the ribosome biogenesis are reduced in the initial stages of the infection [51-55]. Yamamoto et al. (1976) [56] have shown that reduction in protein synthesis, in fact, can be detected between the initial infection stage up to three days after infection (72 h.a.i.).

The present study showed a reduced level of a binding protein to the Rubisco beta subunit in plants of genotype PI561356 72 h.a.i.. A reduction in the accumulation of the transcript corresponding to the Rubisco small subunit was also observed in cultivar Williams 82, 10 days after inoculation with $P$. pachyrhizi [26]. Panthee et al. (2007) [22] also verified a reduction in the same transcript 72 h.a.i. with $P$. pachyrhizi in genotype 5601T. According to Ellis \& Van Der Vies (1988) [57], the chloroplast contains soluble proteins that can bind non-covalently to the small and large Rubisco subunits. These authors indicated that these binding proteins belong to a general class of proteins called "molecular chaperones" which are required for the correct assembly of certain oligomeric proteins such as Rubisco. Our findings might be related to the decreased photosynthetic rates that have been observed in infected plants [26]. Wang et al. (2012) [21] showed that the levels of photosynthesis-related proteins like the Rubisco large subunit were negatively affected upon inoculation with $P$. pachyrhizi. According to these authors the inactivation of anabolic and activation of catabolic pathways might be important to provide energy for plant defense against pathogens. In the present work binding proteins to Rubisco subunit beta, small subunit ribosomal protein $\mathrm{S} 1$ and Elongation factor 1-alpha were all reduced in soybean leaves of resistant genotype PI561356 inoculated with P. pachyrhizi at 72 h.a.i..

We observed increased levels of glutamine synthetase (GS) in plants of genotype PI561356 at 72 h.a.i.. The availability of nitrogen has a significant impact in the development of diseases in plants and GS is one of the key enzymes of the nitrogen metabolism in plant cells [58]. Low availability of nitrogen frequently increases the susceptibility of plants to diseases [59]. Besides, nitrogen limitation can induce pathogenicity related genes in bacteria and pathogenic fungus [60]. In contrast to our observation, Tremblay et al. (2010) [26] verified a reduced accumulation of transcripts corresponding to this protein in the susceptible genotype Williams 8210 days after inoculation. Pageau et al. (2006) [58] observed alterations in the transcription levels of the cytosolic GS (GS1) in tobacco leaves (Nicotiana tabacum L.) inoculated with viral and bacterial pathogens. Increased GS1 level was observed in foliar tissue of infected tobacco plants.

We detected decreased accumulation of gamma-glutamyl hydrolase in plants of genotype PI561356 at 72 h.a.i.. Using 2-D electrophoresis associated with MS, Krishnan et al. (2011) [61] identified gamma-glutamyl hydrolase as a part of the xylem sap in soybean plants. The xylem sap protein composition can be significantly altered by infection with pathogens and this can be detected at distant points of the infection site [62]. Pathogenicity related protein like peroxidades, chitinases and serino-proteases have been detected in great amounts in the xylem sap in several plant species [63]. A proteomic study was conducted by Subramanian et al. (2009) [64] to identify changes in protein accumulation in the soybean xylem sap in response to symbiotic (Bradyrhizobium japonicum) and pathogenic (Phytophthora sojae) interactions. As a result of the pathogenic interaction, the authors verified increased synthesis of several proteins in the xylem sap and a parallel inhibition on fungal development. Rep et al. (2002) [62] observed altered protein accumulation in tomato xylem sap when plants were infected with the fungus Fusarium oxysporum.

The enzyme carbonic anhydrase was highly accumulated at 192 h.a.i. in susceptible genotype Embrapa 48 plants inoculated with P. pachyrhizi (Figure 1B). Unexpectedly, this enzyme that performs important roles in the chloroplast metabolism was not detected in the mock plants. The explanations for this observation could be also related with limitations of the electrophoresis technique and the image analysis software as discussed previously for the fructose bisphosphate aldolase. Carbonic anhydrase is a metalloenzyme that catalyzes the $\mathrm{CO}_{2} /$ $\mathrm{HCO}_{3}{ }^{-}$inter-conversion. In plants the conversion of $\mathrm{HCO}_{3}{ }^{-}$to $\mathrm{CO}_{2}$ supplies the Rubisco enzyme with substrate. In $\mathrm{C}_{4}$ plants, $\mathrm{HCO}_{3}$ - produced from $\mathrm{CO}_{2}$ is fixed by PEPcarboxylase. In $\mathrm{C}_{3}$ plants like soybean, carbonic anhydrase enables carbon diffusion between cytosol and stroma in the form of $\mathrm{HCO}_{3}^{-}$, converting it to $\mathrm{CO}_{2}$ only at the moment of carbon fixation by the Calvin cycle [65].

There are several pieces of evidence showing that carbonic anhydrase is involved with molecular defense mechanisms of plants against pathogens. In plants, salicylic acid (SA) has an important role in the local and systemic defense responses [66]. It is synthesized as a response to biotrophic pathogens [67]. In tobacco leaves, Slaymaker et al. (2002) [66] reported the presence of one SA binding protein (SABP3). The chloroplast soluble fraction was purified by chromatography, and the SA binding activity increased 600 times in the fraction corresponding to SABP3. MS and sequencing data revealed that SABP3 corresponded to carbonic anhydrase. 
Restrepo et al. (2005) [68] analyzed the variation in the gene expression of Solanum tuberosum in its compatible interaction with Phytophthora infestans. The authors observed a decrease in the accumulation of carbonic anhydrase throughout the postinoculation period. The gene encoding this enzyme was silenced in Nicotiana benthamiana and in silenced plants there was a faster development of the pathogen, indicating that in the absence of this enzyme there is an increased susceptibility to $P$. infestans. Panthee et al. (2007) [22] found increased levels of transcripts for SA effector proteins in cultivar $5601 \mathrm{~T}$ at stage $\mathrm{V} 2$ in response to $P$. pachyrhizi. These results, added to the ones found in the present study, indicate a possible function of carbonic anhydrase in the metabolic mechanisms involved in plant defense to pathogens.

In the present study, we noticed an increased DXR level in the susceptible genotype Embrapa 48192 h.a.i.. In chloroplasts as part of the 2-C-methyl-D-erythritol-4-phosphate (MEP) pathway DXR catalyzes the synthesis of MEP which is the precursor of isopentenyl diphosphate and its isomer dimethylallyl diphosphate. These compounds are essential for isoprenoid biosynthesis $[69,70]$. Isoprenoids perform important functions in many aspects of cellular metabolism, including photosynthesis (carotenoids and chlorophyll), respiration (ubiquinone), development regulation (gibberellic acid and abscisic acid) and defense against pathogens (phytoalexins) [71-73].

The genotype Embrapa 48 also presented increased levels of GAPDHa 192 h.a.i.. In the chloroplast, this enzyme is part of the carbon fixation pathway for glucose biosynthesis. Laxalt et al. (1996) [74], using Northern blot, observed increased accumulation of transcripts for cytosolic GAPDH subunit $C$ (GAPDHc) in leaves and stalks of Solanum tuberosum $L$. inoculated with $P$. infestans. When eicosapentaenoic acid, an elicitor produced by $P$. infestans, was applied to the stalk the transcript levels for GAPDHc also increased and in parallel there was induction of the gene encoding for the enzyme hydroxymethylglutaryl coenzyme A reductase, which participates in the synthesis of isoprenoids (phytoalexins). In this same study the authors submitted leaf tissue to salicylic acid and again differential accumulation of transcripts for GAPDHc occurred.

During plant interaction with pathogens, the systemic acquired resistance (SAR) is induced as part of the defense reaction of the plant as a whole. This leads to increased levels of the reactive oxygen intermediates (e.g. $\mathrm{H}_{2} \mathrm{O}_{2}$ ) [75]. Zaffagnini et al. (2007) [76], examining the effects of redox modifications in the activity of the chloroplast isoform of GAPDH from Arabidopsis thaliana showed that this enzyme was inhibited by oxidants like $\mathrm{H}_{2} \mathrm{O}_{2}$. It is plausible to speculate that the increased GAPDHa

\section{References}

[1] Juliatti F.C., Polizel A.C., Balardin R.S., Vale F.X.R., Soybean rust: epidemiology and management for a re-emerging disease, Revis. Anu. Patol. Plantas, 2005, 13, 351-395. [In Port.]

[2] Sinclair J.B., Backman P.A., Compendium of Soybean Diseases, 3rd ed, American Phytopathological Society Press, St Paul, MN, 1989 levels observed in the present work in soybean leaves of plants inoculated with $P$. pachyrhizi is a compensatory response to the reduced activity of the enzyme due to accumulation of $\mathrm{H}_{2} \mathrm{O}_{2}$ as part of the acquired immune response. Wang et al. (2012) [21] also detected increased levels of this protein in soybean leaves inoculated with $P$. pachyrhizi at 12 and 24 h.a.i.

In conclusion, it is clear that most of the differentially accumulated proteins detected in the present study in the interaction between Phakopsora pachyrhizi and soybean genotypes participate in metabolic pathways involved in plant defense against pathogens. The differential accumulation of carbonic anhydrase and GAPDHa, for instance, indicates that SAR was activated upon pathogen inoculation. Carbonic anhydrase is a potential effector of salycilic acid, and GAPDHa activity is inhibited by reactive oxygen compounds that are accumulated during SAR. A decreased synthesis of TCTP could be indicative of a HR which has as one of its processes the PCD, since TCTP has functions proliferative and anti-apoptotic. Our study also detected some proteins with differential synthesis that are potentially involved with plant defense against pathogens, such as DXR, fructose-bisphosphate aldolase and glutamine synthetase that presented highest accumulation after inoculation. The reduced levels of small subunit ribosomal protein S1, elongation factor 1-alpha and binding protein to Rubisco subunit beta are in accordance with the idea that decrease in anabolism and increase in catabolism may generate useful energy that can be used during response to pathogen attack. The gamma-glutamyl hydrolase showed altered accumulation upon $P$. pachyrhizi inoculation. Although the specific functions of this protein in plant defense are still unknown, our findings and those already described in the literature indicate a possible role for this protein in metabolic pathways related to plant defense against pathogens. Our findings not only contribute to the understanding of soybean response to $P$. pachyrhizi, but also corroborate previous information on this important pathosystem.

\section{Acknowledgements}

This study was supported by resources from Genosoja (Consórcio Nacional para Estudos do Genoma da Soja)/ CNPq (Conselho Nacional de Desenvolvimento Científico e Tecnológico), Finep (Financiadora de Estudos e Projetos) and Fapemig (Fundação de Amparo à Pesquisa do Estado de Minas Gerais). We are greatful to the Núcleo de Análise de Biomoléculas of the Universidade Federal de Viçosa for providing the facilities for the conduction of the experiments.

[3] Silva V.A.S., Juliatti F.C., Silva L.A.S., Interaction between partial genetic resistance and fungicides in the control of asian soybean rust, Pesqui. Agropecu. Bras., 2007, 42 (9), 1261-1268. [in Port.]

[4] Miles M.R., Bonde M.R., Nester S.E., Berner D.K., Frederick R.D., Hartman G.L., Characterizing resistance to 
Phakopsora pachyrhizi in soybean, Plant Dis., 2011, 95 (5), 577-581

[5] Yorinori J.T., Paiva W.M., Frederick R.D., Costamilan L.M., Bertagnolli P.F., Hartman G.E., et al., Epidemics of soybean rust (Phakopsora pachyrhizi) in Brazil and Paraguay from 2001 to 2003, Plant Dis., 2005, 89, 675-677

[6] Hartman G.L., Hill C.B., Twizeyimana M., Miles M.R., Bandyopadhyay R., Interaction of soybean and Phakopsora pachyrhizi, the cause of soybean rust, CAB Rev. Perspect. Agric. Vet. Sci. Nutr. Nat. Resour., 2011, 6, doi:10.1079/ PAVSNNR20116025

[7] Miles M.R., Frederick R.D., Hartman G.L., Evaluation of soybean germplasm for resistance to Phakopsora pachyrhizi, Online, Plant Health Progress, 2006 doi:10.1094/PHP-20060104-01-RS.

[8] Soares R.M., Rubin S.A.L., Wielewicki A.P., Ozelame J.G., Fungicidas no controle da ferrugem asiática (Phakopsora pachyrhizi) e produtividade da soja, Cienc. Rural, 2004, 34(4), 1245-1247 [In Port.]

[9] Yorinori J.T., Paiva W.M., Ferrugem da soja: Phakopsora pachyrhizi Sydow, Londrina: Embrapa Soja, 1 Folder, 2002 [In Port.]

[10] Zambolim L., Manejo Integrado da Ferrugem Asiática da Soja, In: Zambolim L. (Editor), Ferrugem Asiática da Soja, Ed. UFV, Viçosa, Cap.5, p. 73-98, 2006

[11] Yorinori J.T., Nunes Júnior J., Lazzarotto J.J., Ferrugem asiática da Soja no Brasil: Evolução, importância econômica e controle, Londrina: Embrapa Soja, 36p, 2004 (Documentos, 247).

[12] Cheng Y.W., Chan K.L., The breeding of rust resistant soybean Tainung 3, J. Taiwan Agr. Res., 1968, 17, 30-35

[13] Hidayat O.O., Somaatmadja S., Screening of soybean breeding lines for resistance to soybean rust (Phakopsora pachyrhizi Sydow), Soybean Rust Newsl., 1977, 1, 9-22

[14] Bromfield K.R., Hartwig E.E., Resistance to soybean rust and mode of inheritance, Crop Sci., 1980, 20, 254-255

[15] Hartwig E.E., Identification of of a fourth major. gene conferring resistance to soybean rust, Crop Sci., 1986, 26, 1135-1136

[16] Garcia A., Calvo E.S., Kiihl R.A.S., Harada A., Hiromoto D.M., Vieira L.G., Molecular mapping of soybean rust (Phakopsora pachyrhizi) resistance genes: discovery of a novel locus and alleles, Theor. Appl. Genet., 2008, 117, 545-553

[17] Li S., Smith J.R., Ray J.D., Frederick R.D., Identification of a new soybean rust resistance gene in $\mathrm{PI} 567102 \mathrm{~B}$, Theor. Appl. Genet., 2012, 125(1), 133-42

[18] Bonde M.R., Nester S.E., Austin C.N., Stone C.L., Frederick R.D., Hartman G.L., et al., Evaluation of virulence of Phakopsora pachyrhizi and P. meibomiae isolates, Plant Dis., 2006, 90 (6), 708-716

[19] Kim K., Unfried J.R., Hyten D.L., Frederick R.D., Hartman G.L., Nelson R.L., et al., Molecular mapping of soybean rust resistance in soybean accession PI 561356 and SNP haplotype analysis of the Rpp1 region in diverse germplasm, Theor. Appl. Genet., 2012, 125, 1339-1352
[20] Goellner K., Loehrer M., Langenbach C., Conrath U.W.E., Koch E., Schaffrath U., Phakopsora pachyrhizi, the causal agent of Asian soybean rust, Mol. Plant Pathol., 2010, 11(2), 169-177

[21] Wang Y., Yuan X., Hu H., Liu Y., Sun W., Shan Z., et al., Proteomic Analysis of Differentially Expressed Proteins in Resistant Soybean Leaves after Phakopsora pachyrhizi Infection, J. Phytopathol., 2012, 160, 554-560

[22] Panthee D.R., Yuan J.S., Wright D.L., Marois J.J., Mailhot D., Stewart Jr. C.N., Gene expression analysis in soybean in response to the causal agent of Asian soybean rust (Phakopsora pachyrhizi. Sydow) in an early growth stage, Funct. Integr. Genomics, 2007, 7, 291-301

[23] Panthee D.R., Marois J.J., Wright D.L., Narváez D., Yuan J.S., Stewart Jr. C.N., Differential expression of genes in soybean in response to the causal agent of Asian soybean rust (Phakopsora pachyrhizi . Sydow) is soybean growth stage-specific, Theor. Appl. Genet., 2009, 118, 359-370

[24] Mortel M.V. de, Recknor J.C., Graham M.A., Nettleton D., Dittman J.D., Nelson R.T., et al., Distinct biphasic mRNA changes in response to Asian soybean rust infection, Mol. Plant-Microbe Interact. (MPMI), 2007, 20, 887-899

[25] Pham T.A., Miles M.R., Frederick R.D., Hill C.B., Hartman G.L., Differential responses of resistant soybean entries to isolates of Phakopsora pachyrhizi, Plant Dis., 2009, 93, 224228

[26] Tremblay A., Hosseini P., Alkharouf N.W., Li S., Matthews B.F., Transcriptome analysis of a compatible response by Glycine max to Phakopsora pachyrhizi infection, Plant Sci., 2010, 179, 183-193

[27] Wilkins M.R., Sanchez J.C., Gooley A.A., Appel R.D., Humphery-Smith I., Hochstrasser D.F., et al., Progress with proteome projects: why all proteins expressed by genome should be identified and how to do it, Biotechnol. Genet. Eng. Rev., 1996, 13, 19-50

[28] Wang W., Scali M., Vignani R., Spadafora A., Sensi E., Mazzuca S., et al., Protein extraction for two-dimensional electrophoresis from olive leaf, a plant tissue containing high levels of interfering compounds, Electrophoresis, 2003, 24 (14), 2369-2375

[29] Bradford M.M., A rapid and sensitive method for the quantitation of microgram quantities of protein utilizing the principle of protein-dye binding, Anal. Biochem., 1976, 72, 248-254

[30] Anonymous: 2-D Electrophoresis: Principles and Methods - Handbook 80-6429-60AC, GE Healthcare, Piscataway 2004.

[31] Laemmli U.K., Cleavage of structural proteins during the assembly of the head of bacteriophage T4, Nature, 1970, 227, 680-685

[32] Shevchenko A., Tomas H., Havlis J., Olsen J.V., Mann M., In-gel digestion for mass spectrometric characterization of proteins and proteomes, Nature, 2006, 1(6), 2856-2860

[33] Hill M.K., Lyon K.J., Lyon B.R., Identification of disease response genes expressed in Gossypium hirsutum upon 
infection with the wilt pathogen Verticillium dahliae, Plant Mol. Biol., 1999, 40, 289-296

[34] Zhao C.J., Wang A.R., Shi Y.J., Wang L.Q., Liu W.D., Wang $Z . H$. , et al., Identification of defense-related genes in rice responding to challenge by Rhizoctonia solani, Theor. Appl. Genet., 2008, 116, 501-516

[35] Liao M., Li Y., Wang Z., Identification of elicitor-responsive proteins in rice leaves by a proteomic approach, Proteomics, 2009, 9, 2809-2819

[36] Brommer U.A., Thiele B.J., The translationally controlled tumour protein (TCTP), Int. J. Biochem. Cell Biol., 2004, 36, 379-385

[37] Sage-Ono K., Ono M., Harada H., Kamada H., Dark-induced accumulation of mRNA for a homolog of translationally controlled tumor protein (TCTP) in Pharbitis, Plant Cell Physiol., 1998, 39, 357-360

[38] Ermolayev V., Weschke W., Manteuffel R., Comparison of Alinduced gene expression in sensitive and tolerant soybean cultivars, J. Exp. Bot., 2003, 54, 2745-2756

[39] Lee J.Y., Lee D.H., Use of serial analysis of gene expression technology to reveal changes in gene expression in Arabidopsis pollen undergoing cold stress, Plant Physiol., 2003, 132, 517-529

[40] Veena, Jiang H., Doerge R.W., Gelvin S.B., Transfer of T-DNA and Vir proteins to plant cells by Agrobacterium tumefaciens induces expression of host genes involved in mediating transformation and suppresses host defense gene expression, Plant J., 2003, 35, 219-236

[41] Sprunck S., Baumann U., Edwards K., Langridge P., Dresselhaus T., The transcript composition of egg cells changes significantly following fertilization in wheat (Triticum aestivum L.), Plant J., 2005, 41, 660-672

[42] Vincent D., Ergül A., Bohlman M.C., Tattersall E.A.R., Tillett R.L., Wheatley M.D., et al., Proteomic analysis reveals differences between Vitis vinifera L. CV. Chardonnay and cV. Cabernet Sauvignon and their responses to water deficit and salinity, J. Exp. Bot., 2007, 58, 1873-1892

[43] MacDonald S.M., Rafnar T., Langdon J., Lichtenstein L.M., Molecular identification of an lgE-dependent histaminereleasing factor, Science, 1995, 269, 688-690

[44] Cans C., Passer B.J., Shalak V., Nancy-Portebois V., Crible V., Amzallag N., et al., Translationally controlled tumor protein acts as a guanine nucleotide dissociation inhibitor on the translation elongation factor eEF1A, Proc. Natl. Acad. Sci. USA, 2003, 100, 13892-13897

[45] Arcuri F., Papa S., Meini A., Carducci A., Romagnoli R., Bianchi L., et al., The translationally controlled tumor protein is a novel calcium binding protein of the human placenta and regulates calcium handling in trophoblast cells, Biol. Reprod., 2005, 73, 745-751

[46] Thiele H., Berger M., Skalweit A., Thiele B.J., Expression of the gene and processed pseudogenes encoding the human and rabbit translationally controlled tumour protein (TCTP), Eur. J. Biochem., 2000, 267, 54735481
[47] Li F., Zhang D., Fujise K., Characterization of fortilin, a novel antiapoptotic protein, J. Biol. Chem., 2001, 276, 4754247549

[48] Lam E., Kato N., Lawton M., Programmed cell death, mitochondria and the plant hypersensitive response, Nature, 2001, 411, 848-853

[49] Heath M.C., Hypersensitive response-relatived death, Plant Mol. Biol., 2000, 44, 321-334

[50] Tsunezuka H., Fujiwara M., Kawasaki T., Shimamoto K., Proteome analysis of programmed cell death and defense signaling using the rice lesion mimic mutant cdr2, Mol. PlantMicrobe Interact., 2005, 18, 52-59

[51] Tani T., Yamamoto H., Nucleic acid and protein synthesis in association with the resistance of oat leaves to crown rust, Physiol. Plant Pathol., 1978, 12, 113-121

[52] Manners J.M., Scott K.J., Translational activity of polysomes of barley leaves during infection by Ersiphe graminis f.sp. hordei, Phytopathology, 1983, 73, 1386-1392

[53] Manners J.M., Scott K.J., Reduced translatable messenger RNA activities in leaves of barley infected with Ersiphe graminis f.sp. hordei, Physiol. Plant Pathol., 1985, 26, 297-308

[54] Heath M.C., Signaling between pathogenic rust fungi and resistant or susceptible host plants, Ann. Bot., 1997, 80, 713-720

[55] Mould M.J.R., Heath M.C., Ultrastructural evidence of differential changes in transcription, translation, and cortical microtubules during in planta penetration of cells resistant or susceptible to rust infection, Physiol. Mol. Plant Pathol., 1999, 55, 225-236

[56] Yamamoto H., Tani T., Hokin H., Protein synthesis linked with resistance of oat leaves to crown rust fungus, Jpn J. Phytopathol., 1976, 42, 583-590

[57] Ellis R.J., Van Der Vies S.M., The Rubisco subunit binding protein, Photosynth. Res., 1988, 16 (1-2), 101-115

[58] Pageau K., Reisdorf-Cren M., Morot-Gaudry J.F., MasclauxDaubresse C., The two senescence-related markers, GS1 (cytosolic glutamine synthetase) and GDH (glutamate dehydrogenase), involved in nitrogen mobilization, are differentially regulated during pathogen attack and by stress hormones and reactive oxygen species in Nicotiana tabacum L. leaves, J. Exp. Bot., 2006, 57(3), 547-557

[59] Solomon P.S., Tan K.C., Oliver R.P., The nutrient supply of pathogenic fungi; a fertile field for study, Mol. Plant Pathol., 2003, 4, 203-210

[60] Talbot N.J., McCafferty H.R.K., Ma M., Moore K., Hamer J.E., Nitrogen starvation of the rice blast fungus Magnaporthe grisea may act as an environmental cue for disease symptom expression, Physiol. Mol. Plant Pathol., 1997, 50, 179-195

[61] Krishnan H.B., Natarajan S.S., Bennett J.O., Sicher R.C., Protein and metabolite composition of xylem sap from fieldgrown soybeans (Glycine max), Planta, 2011, 233, 921-931

[62] Rep M., Dekker H.L., Vossen J.H., de Boer A.D., Houterman P.M., Speijer D., et al., Mass spectrometric identification of isoforms of PR proteins in xylem sap of fungus-infected tomato, Plant Physiol., 2002, 130, 904-917 
[63] Buhtz A., Kolasa A., Arlt K., Walz C., Kehr J., Xylem sap protein composition is conserved among different plant species, Planta, 2004, 219, 610-618

[64] Subramanian S., Cho U-H., Keyes C., Yu O., Distinct changes in soybean xylem sap proteome in response to pathogenic and symbiotic microbe interactions, BMC Plant Biol., 2009, 9, 119

[65] Badger M.R., Price G.D., The role of carbonic anhydrase in photosynthesis, Annu. Rev. Plant Physiol. Plant Mol. Biol., 1994, 45, 369-392

[66] Slaymaker D.H., Navarre D.A., Clark D., del Pozo O., Martin G.B., Klessig D.F., The tobacco salicylic acid-binding protein 3 (SABP3) is the chloroplast carbonic anhydrase, which exhibits antioxidant activity and plays a role in the hypersensitive defense response, Proc. Natl. Acad. Sci. USA, 2002, 99 (18), 11640-11645

[67] Loake G., Grant M., Salicylic acid in plant defence = the players and protagonists, Curr. Opin. Plant Biol., 2007, 10, 466-472

[68] Restrepo S., Myers K.L., del Pozo O., Martin G.B., Hart A.L., Buell C.R., et al., Gene profiling of a compatible interaction between Phytophthora infestans and Solanum tuberosum suggests a role for carbonic anhydrase, Mol. Plant-Microbe Interact., 2005, 18(9), 913-922

[69] Estévez J.M., Cantero A., Reindl A., Reichler S., León P., 1-Deoxy-D-xylulose-5-phosphate synthase, a limiting enzyme for plastidic isoprenoid biosynthesis in plants, J. Biol. Chem., 2001, 276 (25), 22901-22909
[70] Hasunuma T., Takeno S., Hayashi S., Sendai M., Bamba T., Yoshimura S., et al., Overexpression of 1-Deoxy-Dxylulose-5-phosphate reductoisomerase gene in chloroplast contributes to increment of isoprenoid production, J. Biosci. Bioeng., 2008, 105(5), 518-526

[71] Wanke M., Skorupinska-Tudek K., Swiezewska E., Isoprenoid biosynthesis via 1-deoxy-D-xylulose 5-phosphate/2-Cmethyl-D-erythritol 4-phosphate (DOXP/MEP) pathway, Acta Biochim. Pol., 2001, 48(3), 663-672

[72] Flors C., Nonell S., Light and singlet oxygen in plant defense against pathogens: phototoxic phenalenone phytoalexins, Acc. Chem. Res., 2006, 39 (5), 293-300

[73] Kirby J., Keasling J.D., Biosynthesis of Plant Isoprenoids: Perspectives for Microbial Engineering, Annu. Rev. Plant Biol., 2009, 60, 335-355

[74] Laxalt A.M., Cassia R.O., Sanllorenti P.M., Madrid E.A., Andreu A.B., Daleo G.R., et al., Accumulation of cytosolic glyceraldehyde-3-phosphate dehydrogenase RNA under biological stress conditions and elicitor treatments in potato, Plant Mol. Biol., 1996, 30(5), 961-972

[75] Chen Z., Silva H., Klessig D.F., Active oxygen species in the induction of plant systemic acquired resistance by salicylic acid, Science, 1993, 262, 1883-1886

[76] Zaffagnini M., Michelet L., Marchand C., Sparla F., Decottignies P., Le Maréchal P., et al., The thioredoxinindependent isoform of chloroplastic glyceraldehyde3-phosphate dehydrogenase is selectively regulated by glutathionylation, FEBS J., 2007, 274, 212-226 